\title{
PENERAPAN TEKNOLOGI BUDIDAYA KUBIS \\ DI KALANGAN PETANI DESA GENTENG, KECAMATAN SUKASARI, KABUPATEN SUMEDANG, JAWA BARAT
}

\author{
APPLICATION OF CULTIVATION TECHNOLOGY AMONG FARMERS, \\ VILLAGE GENTENG, SUKASARI DISTRICT, SUMEDANG REGENCY, \\ WEST JAVA PROVINCE
}

\author{
REZKHY AMALIA RACHMADHANI*, SRI FATIMA \\ Fakultas Pertanian, Universitas Padjadjaran \\ *E-mail: rezkhyamalia@gmail.com
}

\begin{abstract}
ABSTRAK
Teknologi budidaya kubis merupakan salah satu metode inovasi teknologi untuk meningkatkan produksi tanaman dengan mutu yang berkualitas. Tujuan penelitian ini adalah mengetahui persepsi dan tingkat adopsi petani terhadap penerapan teknologi budidaya kubis serta, mengidentifikasi faktor-faktor yang mempengaruhi adopsi petani terhadap penerapan teknologi budidaya kubis sesuai anjuran. Penelitian ini telah dilaksanakan di Kelompok Tani Tirta Mulya dan Kelompok Tani Jaya Makmur, Desa Genteng, Kecamatan Sukasari, Kabupaten Sumedang, Jawa Barat. Data diperoleh dengan sampel (sensus) sebanyak 46 responden yang menjadi anggota di dua kelompok tani tersebut. Selanjutnya, data diolah secara deskriptif dan dianalisis menggunakan regresi logistik. Data hasil penelitian menunjukkan persepsi peran penyuluhan terhadap penerapan teknologi budidaya dengan kategori positif $63,04 \%$ dan kategori negatif 36,95\%. Persepsi karakteristik inovasi terhadap penerapan teknologi budidaya dengan kategori positif $65,21 \%$ dan kategori negatif 34,78\%. Adopsi petani untuk menerapkan teknologi budidaya kubis sesuai anjuran $73,91 \%$ dan tidak sesuai anjuran $26,08 \%$. Berdasarkan analisis regresi logistik terdapat tiga variabel yang berpengaruh nyata terhadap penerapan teknologi budidaya kubis sesuai anjuran diantaranya usia, pengalaman usahatani, dan persepsi terhadap peran penyuluhan.
\end{abstract}

Kata kunci: regresi logistik, teknologi budidaya kubis, persepsi petani

\section{ABSTRACT}

Cabbage cultivation technology is one method of technology innovation in agriculture to increase production with high quality. The purpose of this research is, to know the perception of farmers on the role of agricultural extension, to know the perception of farmers on the characteristics of innovation, to measure the level of adoption of cultivation technology, and to identify the factors that affect farmers to implement the cultivation technology. This research was conducted at Tirta Mulya Farmer Group and Jaya Makmur Farmer Group. Both farmer groups are located in Genteng Village, Sukasari District, Sumedang Regency, West Java. There are 46 respondents as a sample of this research. Furthermore, the data is processed with descriptive and logistic regression analysis. The result of the research show that perception related to role of agricultural extension, with positive category $63,04 \%$, and negative category $36,95 \%$. Perceptions related to the characteristics of innovation, with positive category $65.21 \%$, and negative category $34.78 \%$. The adoption rate of farmers to implement the technology is $73.91 \%$, and adoption of farmers not implement the technology is $26.08 \%$. Based on the results of logistic regression analysis, there are three variables that influence the application of technology as recommended, such as age, farming experience, and perception related to the role of agricultural extension.

Keywords: logistic regression, cabbage culture technology, farmer's perception 


\section{PENDAHULUAN}

Indonesia merupakan negara agraris yang sebagian besar penduduknya berprofesi sebagai petani, iklim dan kondisi geografis Indonesia yang beragam di satu wilayah dengan wilayah lainnya sangat cocok untuk ditanami berbagai jenis tanaman. Menurut BPS (2016), sektor pertanian merupakan salah satu lapangan usaha yang mempunyai peran penting dalam perekonomian Indonesia terutama dalam pembentukan PDB. Lapangan usaha sektor pertanian dalam pembentukan PDB mengalami kenaikan sebesar 3.3\% dari tahun 2016-2017.

Komoditas hortikultura menjadi salah satu jenis tanaman yang potensial untuk dikembangkan di Indonesia, selain itu hortikultura merupakan komoditas pertanian yang memilki harga cukup tinggi di pasaran. Maka dapat mendatangkan keuntungan bagi petani sehingga banyak petani Indonesia yang membudidayakan tanaman hortikultura (Khoirunnisa et al, 2013).

Kubis merupakan salah satu komoditas hortikultura yang paling banyak dikembangkan di Indonesia, disusul oleh kentang, bawang merah, cabai, dan tomat (BPS, 2016). Menurut Kementerian Pertanian (2012), kubis merupakan penyumbang terbesar dengan volume ekspor sebesar 59.855 ton senilai US\$ 11.450 ribu. Berdasarkan data BPS (2016), produksi kubis di Indonesia pada tahun 2016 mencapai 1.513.315 ton. Provinsi Jawa barat merupakan penyumbang terbesar kedua hasil produksi kubis terbanyak di Indonesia. Produksi kubis di Jawa Barat tahun 2016 mencapai 310.852 ton dengan total luas panen 13.394 ha.

Kabupaten Sumedang merupakan salah satu wilayah keempat terbanyak setelah Garut, Bandung dan Cianjur yang berkontribusi meningkatkan produksi kubis di Jawa Barat. Produksi kubis di Kabupaten Sumedang mengalami angka yang fluktuatif, umumnya penurunan produksi seiring dengan penurunan luas panennya yang disebabkan peralihan lahan hortikultura menjadi lahan perkebunan. Dan kenaikan produksi disebabkan adanya program bantuan dari pemerintah seperti bibit, mulsa, dan obatobatan (BPS, 2016). Selain itu masalah utama yang dihadapi agribisnis sayuran diantaranya teknik budidaya belum sesuai dengan Standard Operating Procedure (SOP), produknya bermutu rendah, biaya produksi tinggi, resiko pola tanam yang tidak tepat, serta penggunaan benih dengan mutu asalan (Khoirunnisa et al, 2013). 
Kecamatan Sukasari berlokasi di Kabupaten Sumedang, terdapat tujuh desa yang berlokasi di Kecamatan Sukasari. Desa Genteng merupakan desa yang memiliki produksi kubis paling tinggi di Kecamatan Sukasari. Di Desa Genteng terdapat 1 GAPOKTAN yang terdiri atas 32 kelompok tani, tetapi hanya dua kelompok tani yang mengusahakan usahatani kubis setiap tahun dan beberapa anggotanya memiliki sertifikat lahan dan kebun yang kemudian dapat menghasilkan produk prima 3.

Dalam menerapkan teknologi budidaya sesuai anjuran secara rutin tidak lepas dari adanya peran penyuluhan pertanian dan karakteristik inovasi terhadap teknologi budidya dengan tujuan untuk menghasilkan produk yang berkualitas. Kedua kelompok tani pernah mendapatkan penyuluhan teknologi budidaya kubis atau teknologi inovasi pertanian lainnya seperti pembuatan pestisida organik dan pembuatan pupuk hayati yang diterapkan dengan metode demonstration plot (demplot). Adanya Sekolah Lapang (SL) yang diberikan kepada petani juga merupakan salah satu cara dari penyuluh yang bertujuan untuk menambah wawasan dan hasil produksi usahatani.

Berdasarkan wawancara dengan Ketua Kelompok Tani dan Penyuluh Pertanian bantuan pemerintah yang pernah diberikan sudah berjalan dari tahun 2015 diantaranya yaitu, program Unit Pengolah Pupuk Organik (UPPO), program Jalan Usaha Tani (JUT), dan program pengembangan kubis seluas 2 ha pada tahun 2016 .

Penerapan teknologi budidaya kubis meliputi beberapa aspek dari Fase Persemaian-Pascapanen. Dari beberapa penelitian yang telah ditulis menunjukkan bahwa jika penerapan teknologi budidaya dijalani sesuai SOP, berdampak pada peningkatan produksi usahatani yang akhirnya dapat meningkatkan pendapatan usahatani. Input yang digunakan pada penerapan teknologi budidaya kubis juga mengikuti dosis yang dianjurkan maka dapat menekan biaya usahatani, jika penggunaannya teratur dan tidak boros. Jadi fokus penelitian ini bertujuan untuk mengetahui persepsi dan tingkat adopsi petani terhadap penerapan teknologi budidaya kubis serta, mengidentifikasi faktor-faktor yang mempengaruhi adopsi petani terhadap penerapan teknologi budidaya kubis sesuai anjuran 


\section{METODE PENELITIAN}

Objek penelitian adalah petani kubis Kelompok Tani Tirta Mulya dan Kelompok Tani Jaya Makmur. Kelompok Tani Tirta Mulya terletak di Dusun Pasir Kaliki, sedangkan Kelompok Tani Jaya Makmur terletak di Dusun Pasirhantap. Kedua Kelompok Tani tersebut berlokasi di Desa Genteng Kecamatan Sukasari Kabupaten Sumedang. Lokasi penelitian dipilih dengan dasar pertimbangan bahwa petani kubis di dua Kelompok Tani mengusahakan budidaya kubis setiap tahunnya, pernah mendapatkan penyuluhan penerapan teknologi budidaya kubis, dan beberapa anggotanya sudah memiliki sertifikat lahan dan kebun. Total anggota petani pada kedua Kelompok Tani diambil secara sampling jenuh (sensus) dengan jumlah 46 orang.

Metode yang digunakan pada penelitian ini yaitu analisis deskriptif untuk menggambarkan penerapan teknologi budidaya kubis dan persepsi petani. Selain itu untuk melihat pengaruh dari beberapa faktor terhadap penerapan teknologi budidaya kubis sesuai anjuran menggunakan analisis regresi logistik.

Operasionalisasi variabel yang dugunakan pada penelitian ini yaitu:

1. Tingkat adopsi penerapan teknologi budidaya kubis sesuai anjuran yang dikemukakan oleh oleh Tim Agro Nusantara yang ditulis Blankoku (2016) dan BPTP Jambi Barat yang ditulis Edi (2010). Meliputi sebelas aspek yaitu sterilisasi benih, media persemaian, pemindahan bibit ke lahan, jarak tanam, pemupukan berimbang, penyulaman, pengairan, penyiangan, pengendalian hama, tumpangsari, dan pascapanen yang bertujuan mendapatkan hasil yang optimal. Langkah pengukuran tingkat adopsi sebagai berikut:

- Pengukuran variabel penerapan teknologi budidaya diukur dengan skala dikotomik (Menerapkan/Tidak menerapkan)

- Untuk jawaban selalu menerapkan diberi angka 1 dan tidak/jarang menerapkan diberi angka 0

- Kemudian diformulasikan dan diklasifikasikan sebagai berikut Hendayana (2016):

$$
T A=\frac{N F}{T} X 100 \%
$$

\section{Keterangan :}

TA :Tingkat adopsi (\%)

NF :Jumlah teknologi yang selalu diaplikasikan

$\mathrm{T}$ :Total komponen teknologi yang dianjurkan 
Tabel 1 Interpretasi Adopsi Inovasi

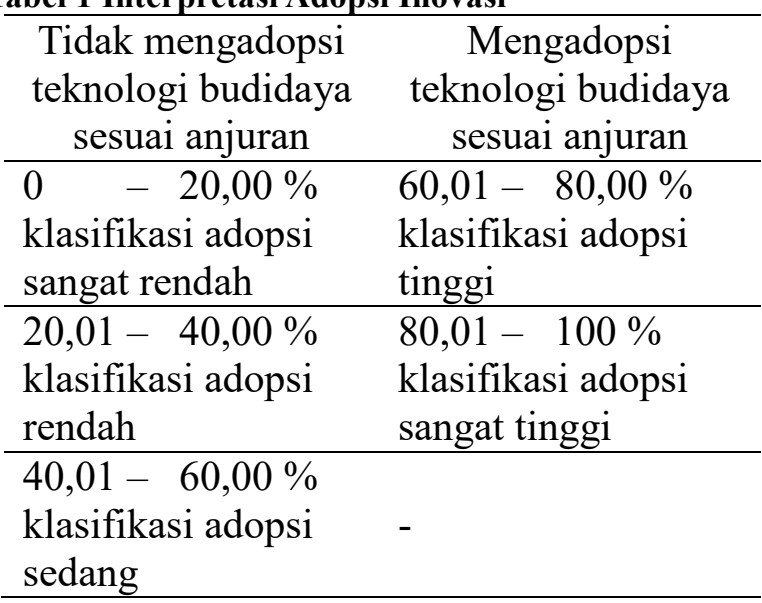

2. Faktor-faktor yang mempengaruhi penerapan teknologi budidaya meliputi beberapa factor, yaitu:

- Usia, ditentukan pada saat penelitian dilakukan. Skala pengukuran yaitu skala dikotomi dalam satuan tahun dikelompokkan menjadi dua kategori produktif dan tidak produktif.

- Tingkat pendidikan, adalah jenjang pendidikan formal yang pernah diraih oleh petani. Skala pengukuran yaitu skala ordinal dalam satuan tahun dikelompokkan berdasarkan SD, SMP, SMA, dan STRATA

- Pengalaman usahatani, yaitu lamanya pengalaman petani dalam mengelola usahatani kubis (tahun). Skala pengukuran yaitu skala kategori dalam satuan tahun dikelompokkan berdasarkan dua kategori yaitu $\leq 10$ tahun dan $>11$ tahun (Soeharjo dan Patong, 1999)

- Luas lahan usahatani kubis, merupakan keseluruhan luas lahan yang diusahakan petani, baik petani pemilik dan petani penyewa. Skala pengukuran yaitu skala kategori dalam satuan $\mathrm{Ha}$ dikelompokkan berdasarkan lahan garapan sempit $\leq 0,5 \mathrm{Ha}$, lahan garapan sedang 0,5-2 $\mathrm{Ha}$, dan lahan garapan luas, $\geq 2 \mathrm{Ha}$. (Hernanto, 1993)

- Persepsi peran penyuluhan terdiri atas 25 pernyataan, meliputi lima indikator yaitu motivator, inovator, fasilitator, komunikator, dan organisator. Data skor persepsi peran penyuluhan diukur menggunakan skala likert dengan interpretasi setiap skor yaitu:

Hasil tabulansi skor kemudian dikategorikan menjadi dua kategori yaitu persepsi positif dan persepsi negatif, persepsi positif menunjukkan bahwa objek sesuai dengan apa yang diharapkan sedangkan persepsi negatif menunjukkan bahwa objek tidak sesuai dengan apa yang diharapkan (Ating dan Muhidin, 2006). Kategori persepsi positif jika skor $>$ Q3 dan kategori persepsi negatif jika skor $\leq$ Q3. 
- Persepsi karakteristik inovasi terdiri atas 10 pernyataan meliputi lima indikator yaitu keuntungan relatif (relative advantage), kesesuaian (compatibility), kerumitan (complexity), kemudahan untuk dicoba (triability), kemudahan untuk dilihat hasilnya (observability). Data skor persepsi karakteristik inovasi diukur menggunakan skala likert dengan interpretasi setiap skor sama dengan Tabel 3

Tabel 2 Interpretasi Skor dalam Skala Likert

\begin{tabular}{ll}
\hline 5=Sangat Setuju (SS) & $\begin{array}{l}\text { Jika responden sependapat dengan pernyataan, selalu } \\
\text { mengalami kejadian sesuai pernyataan. }\end{array}$ \\
\hline 4=Setuju (S) & $\begin{array}{l}\text { Jika responden sependapat dengan pernyataan, namun } \\
\text { tidak selalu mengalami kejadian sesuai pernyataan. }\end{array}$ \\
\hline 3=Ragu-ragu (RR) & $\begin{array}{l}\text { Jika responden kurang sependapat dengan pernyataan, } \\
\text { namun tidak selalu mengalami kejadian sesuai } \\
\text { pernyataan, lebih cenderung tidak mengalami kejadian } \\
\text { sesuai pernyataan. }\end{array}$ \\
\hline 2=Tidak Setuju (TS) & $\begin{array}{l}\text { Jika responden tidak sependapat dengan pernyataan, } \\
\text { sangat jarang mengalami kejadian sesuai pernyataan. }\end{array}$ \\
1=Sangat Tidak Setuju (STS) & $\begin{array}{l}\text { Jika responden tidak sependapat dengan pernyataan, } \\
\text { tidak pernah mengalami kejadian sesuai pernyataan. }\end{array}$ \\
\hline
\end{tabular}

Sumber: Harianto (2014)

3. Model Regresi Logistik

$$
\begin{gathered}
Y=C+\beta_{1} x_{1}+\beta_{2} x_{2}+\beta_{3} x_{3}+\cdots \\
+\beta_{6} x_{6}
\end{gathered}
$$

Keterangan:

:Peluang adopsi $(0=$ Tidak

Y mengadopsi sesuai anjuran, $1=$ Mengadopsi sesuai anjuran)

C :Konstanta

$x_{1} \quad$ :Usia

$x_{2} \quad$ :Pendidikan Formal

$x_{3} \quad$ :Pengalaman usahatani
Hasil tabulansi skor kemudian dikategorikan menjadi dua kategori yaitu persepsi positif dan persepsi negatif, persepsi positif menunjukkan bahwa objek sesuai dengan apa yang diharapkan sedangkan persepsi negatif menunjukkan bahwa objek tidak sesuai dengan apa yang diharapkan (Ating dan Sambas, 2006). Kategori persepsi positif jika skor $>$ Q3 dan kategori persepsi negatif jika skor $\leq \mathrm{Q} 3$ 
windows.

\section{Hipotesis}

H1 : Faktor usia, pendidikan formal, pengalaman usahatani, luas lahan, persepsi peran penyuluhan, dan persepsi karakteristik inovasi mempengaruhi keputusan petani terhadap penerapan teknologi budidaya kubis sesuai anjuran. H0 : Faktor usia, pendidikan formal, pengalaman usahatani, luas lahan, persepsi peran penyuluhan, dan persepsi karakteristik inovasi tidak mempengaruhi keputusan petani terhadap penerapan teknologi budidaya kubis sesuai anjuran.

\section{HASIL DAN PEMBAHASAN}

\section{Profil Petani}

Usia dapat mempengaruhi kemauan dan kemampuan petani dalam melaksanakan kegiatan usahatani, semakin produktif usia maka, semakin mudah dalam melaksanakan kegiatan usahatani, menerima pembaharuan, dan semangat dan kemampuan dalam mengelola usahatani. Anggota kelompok tani yang menjadi sampel dalam penelitian berumur antara 31-77 tahun, dengan proporsi terbanyak $84,78 \%$ pada usia produktif 31-56 tahun.

Pendidikan mempunyai peranan yang sangat penting dalam menjalankan kegiatan pertanian serta dalam meningkatkan usahatani, semakin tinggi pendidikan seorang petani maka akan semakin mudah petani tersebut dalam memperoleh dan memahami suatu teknologi baru yang lebih baik untuk kemajuan pertanian. Dalam memperoleh informasi yang beredar dimasyarakat akan lebih cepat diserap dan dipahami oleh petani sehingga dapat menerapkan informasi tersebut sesuai dengan harapan dan anjuran yang telah ada untuk kegiatan usahatani. Tingkat Pendidikan yang telah ditempuh oleh petani pada penelitian ini yaitu SD sebesar 45,65\% dan SMP sebesar $54,34 \%$

Pengalaman usahatani memiliki peranan penting dalam kegiatan usahatani, semakin lama petani tersebut melakukan kegiatan usahatani umumnya semakin mudah petani untuk meyerap informasi dan mempraktekan inovasi budidaya yang baru. Semakin berpengalaman seseorang juga semakin banyak informasi yang telah diterima dan menambah pengetahuan dan keterampilan petani dalam kegiatan pertanian yang diusahakannya, serta dampak yang terjadi. Pada penelitian ini petani yang memiliki pengalaman $\leq 10$ tahun sebesar $34,78 \%$ dan petani yang memiliki pengalaman $>11$ tahun sebesar $65,21 \%$ 
Luas lahan dalam kegiatan pertanian berpengruh terhadap pengambilan keputusan suatu usahatani. Semakin luas lahan yang dikerjakan oleh petani maka akan semakin berat pula petani mengambil keputusan dalam menggunakan teknologi budidaya inovasi baru yang diterima. Umumnya semakin luas lahan yang digarap oleh petani mempunyai pendapatan yang lebih tinggi dibandingkan petani yang memiliki lahan lebih sedikit. Luas lahan garapan petani pada penelitian ini luas lahan sempit $<0,5$ Ha sebesar 43,47\% dan luas lahan sedang 0,-2 Ha sebesar 56,52\%. Dari 46 responden pada penelitian ini status penggunaan lahan sebagai pemilik penggarap.

\section{Persepsi Peran Penyuluhan}

Persepsi petani menggambarkan sudut pandang responden terhadap peran penyuluhan. Persepsi dikategorikan menjadi dua yaitu persepsi (positif $>$ QIII) dan (negatif $\leq$ QIII). Hasil formulasi variabel persepsi peran penyuluhan, pada penelitian ini didominasi kategori positif sebanyak 29 orang $(63,04 \%)$ yang artinya sudut pandang responden terhadap peran penyuluh sesuai dengan apa yang diharapkan, sedangkan kategori negatif sebanyak 17 orang yang artinya sudut pandang responden terhadap peran penyuluh tidak sesuai dengan apa yang diharapkan (36,95\%). Terdapat lima indikator dalam peran penyuluhan, dari hasil formulasi indikator yang didominasi dengan kategori positif yaitu motivator, komunikator, dan organisator. Sedangkan indikator yang didominasi dengan kategori negatif yaitu inovator dan fasilitator.

\section{Persepsi Karakteristik Inovasi}

Persepsi petani menggambarkan sudut pandang responden dari karakteristik inovasi teknologi budidaya yang diberikan penyuluh. Persepsi dikategorikan menjadi dua yaitu persepsi (positif $>$ QIII) dan (negatif $\leq$ QIII). Pada penelitian ini responden menjawab pernyataan kategori positif sebanyak 30 orang $(65,21 \%)$ yang artinya sudut pandang responden pada karakteristik inovasi yang diberikan sesuai dengan apa yang diharapkan, sedangkan kategori negatif sebanyak 16 orang $(34,78 \%)$ yang artinya sudut pandang responden pada karakteristik inovasi yang diberikan tidak sesuai dengan apa yang diharapkan. Terdapat lima indikator dalam karakteristik inovasi, dari hasil formulasi indikator yang didominasi dengan kategori positif yaitu kemudahan dilihat hasilya (observability), sedangkan indikator yang didominasi dengan 
kategori negatif yaitu keuntungan relatif (relative Advantage), kerumitan (complexity), kemudahan untuk dicoba (triability). Dan Indikator kesesuaian (compatibiliy) berjumlah netral.

\section{Tingkat Adopsi Penerapan Teknologi Budidaya Kubis}

Dari 46 responden penelitian ini menanam kubis pada lahan sawah tadah hujan, berdasarkan penelitian Huda et al (2015) produktivitas dan pendapatan usahatani kubis pada lahan sawah tadah hujan lebih besar dibandingkan dengan produktivitas dan pendapatan usahatani kubis pada lahan kering. Selain itu, responden melakukan rotasi tanam umumnya dengan tomat, cabai, dan tembakau. Waktu penanaman kubis yang dilakukan oleh responden pada musim hujan (bulan oktober-bulan april) dengan tujuan meminimalisir hama. Pada saat melakukan budidaya kubis umumnya responden mencatat masalah yang terjadi sebagai bahan evaluasi.

Dari hasil penelitian yang dilakukan, menunjukkan bahwa dari sebelas aspek penerapan teknologi budidaya usahatani kubis terdapat 34 orang $(26,08 \%)$ yang rutin menerapkan sesuai anjuran, sedangkan 12 orang $(73,91 \%)$ tidak rutin menerapkan sesuai anjuran.

Dari hasil pengisian kuesioner dengan 46 responden, pada sebelas aspek teknologi. Aspek penyiangan didominasi dengan kategori tidak menerapkan, sedangkan aspek sterilisasi benih, media persemaian, pemindahan bibit ke lahan, jarak tanam, pemupukan berimbang, penyulaman, pengairan, pengendalian hama, tumpangsari, dan pascapanen didominasi dengan kategori menerapkan.

\section{Faktor-faktor yang Mempengaruhi Penerapan Teknologi Budidaya Kubis}

Faktor-faktor yang diduga memiliki pengaruh dengan penerapan teknologi budidaya kubis yaitu usia, pendidikan formal, pengalaman usahatani, luas lahan, persepsi terhadap peran penyuluhan, dan persepsi terhadap karakteristik inovasi. Dari hasil analisis regresi logistik menunjukkan bahwa dari 6 faktor yang dianalisis hanya ada 3 faktor yang secara signifikan berpengaruh nyata terhadap penerapan teknologi budidaya sesuai anjuran. Ketiga faktor tersebut adalah usia, pengalaman usahatani, dan persepsi terhadap peran penyuluhan. 
Tabel 3 .Analisis Regresi Logistik (Variables in the Equation)

\begin{tabular}{|c|c|c|c|c|c|c|}
\hline Predictor & B & SE.Coef & Wald & Sig & Exp (B) & \multirow[b]{2}{*}{ Keterangan } \\
\hline Constant & $-5,091$ & 2,034 & 6,264 & 0,012 & 0,006 & \\
\hline Usia & 3,567 & 1,528 & 5,446 & 0,020 & 35,401 & Sig $<0,05$ \\
\hline Pendidikan & 0,453 & 1,314 & 0,119 & 0,730 & 1,572 & $\begin{array}{c}\text { Tidak } \\
>0,05\end{array}$ \\
\hline $\begin{array}{l}\text { Pengalaman } \\
\text { usahatani }\end{array}$ & 3,122 & 1,489 & 4,395 & 0,036 & 22,684 & Sig $<0,05$ \\
\hline Luas lahan & 0,096 & 1,155 & 0,007 & 0,934 & 1,100 & $\begin{array}{l}\text { Tidak } \quad \text { sig } \\
>0,05\end{array}$ \\
\hline $\begin{array}{l}\text { Persepsi } \\
\text { peran } \\
\text { penyuluh }\end{array}$ & 2,231 & 1,291 & 2,985 & 0,084 & 9,309 & Sig $<0,1$ \\
\hline $\begin{array}{l}\text { Persepsi } \\
\text { karakteristik } \\
\text { inovasi }\end{array}$ & 0,582 & 1,263 & 0,212 & 0,645 & 1,789 & $\begin{array}{l}\text { Tidak } \quad \text { sig } \\
>0,05\end{array}$ \\
\hline
\end{tabular}

Adapun model yang dihasilkan

dari pengujian terhadap model regresi logistik adalah sebagai berikut: $L n=$ $\frac{p}{1-p}=-5,091+3,567$ usia +

0,453pendidikan +

\section{3,122pengalaman usahatani +}

\section{0,96 luas lahan +}

\section{2,231persepsi peran penyuluhan +}

0,582persepsi karakteristik inovasi

\section{Usia}

Variabel usia menunjukkan koefisien regresi sebesar 3,567 yang bernilai positif dengan tingkat signifikansi $(0,020<0,05)$. Jadi dapat disimpulkan bahwa usia berpengaruh nyata terhadap penerapan teknologi budidaya sesuai anjuran. Dari koefisen Odds Ratio 35,40 artinya peluang petani mengadopsi teknologi budidaya sesuai anjuran pada usia produktif dapat mencapai 35 kali memungkinkan dibandingkan dengan petani dengan usia tidak produktif.

\section{Tingkat Pendidikan}

Variabel pendidikan menunjukkan koefisien regresi sebesar 0,453 yang bernilai positif dengan tingkat signifikansi $(0,730>0,05)$. Jadi dapat disimpulkan bahwa pendidikan tidak berpengaruh terhadap penerapan teknologi budidaya sesuai anjuran. Dari koefisien Odds Ratio menunjukkan 1,57 yang artinya peluang petani mengadopsi teknologi budidaya sesuai anjuran pada tingkat SMP mencapai 2 kali memungkinkan dibandingkan dengan petani yang mengenyam pendidikan di tingkat SD.

\section{Pengalaman Usahatani}

Variabel pengalaman usahatani menunjukkan koefisien regresi sebesar 3,122 yang bernilai positif dengan tingkat signifikansi $(0,036<0,05)$. Jadi dapat disimpulkan bahwa pengalaman usahatani berpengaruh nyata terhadap penerapan teknologi budidaya sesuai anjuran. Dari koefisien Odds Ratio menunjukkan 22,68 yang artinya peluang petani mengadopsi teknologi budidaya sesuai anjuran dengan pengalaman $>11$ tahun mencapai $23 \mathrm{kali}$ memungkinkan dibandingkan dengan petani yang hanya mempunyai pengalaman $\leq 10$ tahun.

\section{Luas Lahan}

Variabel luas lahan menunjukkan koefisien regresi sebesar 0,096 yang 
bernilai positif dengan tingkat signifikansi $(0,934>0,05)$. Jadi dapat disimpulkan bahwa luas lahan tidak berpengaruh terhadap penerapan teknologi budidaya sesuai anjuran. Dari koefisien Odds Ratio menunjukkan 1,10 yang artinya peluang petani mengadopsi teknologi budidaya sesuai anjuran dengan menggarap lahan sedang mencapai 1 kali memungkinkan dibandingkan dengan petani yang menggarap lahan sempit .

\section{Persepsi Peran Penyuluhan}

Variabel persepsi peran penyuluhan terhadap teknologi budidaya sesuai anjuran menunjukkan koefisien regresi sebesar 2,231 yang bernilai positif dengan tingkat signifikansi $(0,084<0,1)$. Jadi dapat disimpulkan bahwa persepsi peran penyuluhan berpengaruh nyata terhadap penerapan teknologi budidaya sesuai anjuran. Dari koefisien Odds Ratio menunjukkan 9,30 yang artinya peluang petani mengadopsi teknologi budidaya sesuai anjuran dengan persepsi positif 9 kali memungkinkan dibandingkan dengan petani yang memiliki persepsi negatif.

\section{Persepsi Karakteristik Inovasi}

Variabel persepsi karakteristik inovasi terhadap teknologi budidaya sesuai anjuran menunjukkan koefisien regresi sebesar 0,582 yang bernilai positif dengan tingkat signifikansi $(0,645>0,05)$.
Jadi dapat disimpulkan bahwa persepsi karakteristik inovasi tidak berpengaruh terhadap penerapan teknologi budidaya sesuai anjuran. Dari koefisien Odds Ratio menunjukkan 1,78 yang artinya peluang petani mengadopsi teknologi budidaya sesuai anjuran dengan persepsi positif 2 kali memungkinkan dibandingkan dengan petani yang memiliki persepsi negatif.

\section{KESIMPULAN DAN SARAN}

1. Persepsi peran penyuluhan terhadap teknologi budidaya kategori postif sebanyak 29 orang $(63,04 \%)$, sedangkan persepsi kategori negatif sebanyak 17 orang (36,95\%). Persepsi karakteristik inovasi terhadap teknologi budidaya kategori postif sebanyak 30 orang $(65,21 \%)$, sedangkan persepsi kategori negatif sebanyak 16 orang $(34,78 \%)$.

2. Petani yang mengadopsi komponen teknologi budidaya kubis sesuai anjuran sebanyak 34 orang (73,91\%), sedangkan petani yang tidak mengadopsi komponen teknologi budidaya kubis tidak sesuai anjuran sebanyak 12 orang $(26,08 \%)$. Petani yang mengadopsi teknologi budidaya sesuai anjuran dapat menghasilkan 4-6 ton/ha dengan jumlah 2000 pohon. Dikarenakan adanya peningkatan hasil 
produksi dan pendapatan usahatani, maka teknologi budidaya yang direkomendasikan layak untuk diterapkan.

3. Berdasarkan hasil analisa regresi logistik, terdapat tiga faktor yang mempengarui petani terhadap penerapan teknologi budidaya kubis sesuai anjuran meliputi usia, pengalaman usahatani, dan peran penyuluhan.

\section{Saran}

1. Penyuluhan rutin dilakukan 1-2 bulan sekali, tetapi masih belum ada kerjasama yang diterapkan. Untuk lebih berkembang sebaiknya diterapkan kerjasama dengan pihak swasta/instansi lain, bukan hanya dengan bandar saja.

2. Penerapan teknologi budidaya kubis perlu diterapkan karena terbukti dapat meningkatkan hasil produksi lebih optimal

\section{DAFTAR PUSTAKA}

Aini, H.N, dkk. 2015. Analisis Pendapatan dan Risiko Usahatani Kubis Pada Lahan Kering dan Lahan Sawah Tadah Hujan di Kecamatan Gisting Kabupaten Tanggamus. Jurnal Ilmu-Ilmu Agribisnis, 3(1),1-9.
Ating, S. dan Muhidin, Sambas Ali. 2006. Aplikasi Statistika Dalam Penelitian. Bandung: Pustaka Setia Blankoku, M. 2016. Budidaya Kubis Dengan Teknologi Organik

Edi, Syafri dan Bobihoe, Julistia. 2010. Budidaya Tanaman Sayuran. Jambi. Harianto, A. 2014.Tingkat Persepsi dan Adopsi Petani Padi Terhadap Penerapan System of Rice Intensification (SRI) di Desa Simarasok, Sumatera Barat. Skripsi IPB: Fakultas Ekonomi dan Manajemen.

Hendayana, R. 2016. Teori dan Praktek Pengukuran Persepsi dan Adopsi Teknologi Inovasi.

Hernanto, F. 1993. Ilmu Usahatani. Jakarta: Swadaya

Khoirunnisa, A. dkk . 2013. Analisis Pendapatan dan Pengambilan Keputusan dalam Menentukan Tanaman Sayuran Unggulan di Kecamatan Gisting Kabupaten Tanggamus. Jurnal Ilmu-Ilmu Agribisnis, 1(2),98-104

Luthfianti, N.A. 2014. Evaluasi Peran Pendamping terhadap Keberhasilan Program Desa Mandiri Pangan di Kabupaten Bantul. Skripsi: Universitas Gadjah Mada.

Rogers, E.M. 1995. Diffusion of Innovation. Usa: The Free Press

Rogers, E.M. dan Shoemaker, F.F. 1971. Communication of Innovation: A Cross Cultural Approach. New York: The Free Press.

Setiana, L. 2005. Teknik Penyuluhan Dan Pemberdayaan Masyarakat. Bogor: Ghalia Indonesia.

Soeharjo, A. dan Patong, D. 1999. SendiSendi Pokok Ilmu Usahatani.

Bogor: IPB 